particularly difficult without a licensee. The argument is that for each hovercraft Bell and Mitsubishi build, $\mathrm{BHC}$ will receive royalty payments and that, if hovercraft establish themselves, there will be enough business for all three.

The British Hovercraft Corporation is hoping that the breakthrough to profitability will be soon. Next month, its first serious attempt to capture a share of the transport market, the $S R N 4$, will be rolled out from the factory at Cowes. (BHC firmly uses aircraft terminology, so that the $S R N 4$ will not be "launched"; the Board of Trade, not yet sure how to define hovercraft, is to invent a special category for them.) Although the nine-ton $S R N$ 6, which can carry 38 passengers, has been used on regular scheduled services within the British Isles and for pleasure trips from seaside beaches, it is a calm-water hovercraft. $S R N 4$, as well as being nearly twenty times as big, will have to operate in far worse conditions. It will weigh 160 tons, and be capable of carrying 800 commuter passengers, or 256 people and 30 cars at a speed of 70 knots. This is clearly a great advance, but potential buyers are behaving warily. So far, only two have appeared. Hoverlloyd, a Swedish company, has ordered two for a service between Ramsgate and Calais, and British Rail has ordered one. If these two operators are successful, other buyers will undoubtedly come forward.

It is hard to feel as optimistic about another hovercraft project announced last week. Several months after NRDC proposed the idea, the Ministry of Technology approved the construction and operation of a tracked hovercraft in East Anglia. The tersely worded announcement from the ministry gave few details of the project, the broad outlines of which have been established after computer studies and model testing at Hythe. The design provides for hovercars 50 feet long by 10 feet wide, weighing 10 tons and running on a $\mathrm{T}$-shaped reinforced concrete beam 4 feet from the ground. The cars would be propelled by the linear induction motor developed by Professor E. R. Laithwaite at Imperial College, London, and would reach a speed of 300 m.p.h. In order to test these ideas at full scale, twenty miles of fenland north of Cambridge have been obtained on lease from the Great Ouse River Authority, and a track will be built there. The ministry says that the cost will be $£ 2$ million over the first two to three years, but nobody seriously believes that will be the final cost. The track alone will cost more-probably $£ 0 \cdot 25$ million a mile for a device of 70 tons. The experiment may well be cheaper, but if 300 m.p.h. is to be reached at least 20 miles of track will be needed. It is hard to see how this could be done for less than $£ 3$ million, and then it will be necessary to build a vehicle filled with electronic equipment. By publishing a figure of $£ 2$ million, even with the proviso that it will cover only the first few years, the ministry has laid itself open to criticism when, in five or ten years time, the cost turns out to be $£ 5$ million or even $£ 10$ million.

Certainly it will be possible for tracked hovercraft to provide a more rapid service than conventional trains or the aircraft now in service. Even allowing for improvements in transport between airports and city centres, a hovercraft travelling at 300 m.p.h. would still be quicker on journeys of up to 600 miles. This assumes that hovercraft would be allowed to operate from city centres, but that is plausible. Hovercraft may be able to compete with aircraft, but this calculation takes no account of the improvements which are possible in conventional train services.

The estimates produced by HDL make tracked hovercraft seem a dubious proposition. Double track would cost about $£ 0.5$ million a mile, and one car, seating 200 , would cost $£ 420,000$. For routes handling fewer than 2 million passengers each year, air travel would be cheaper. At higher densities, the figures begin to look more attractive, but only on routes handling more than 6 million passengers a year would hovercraft be able to offer cheaper transport than trains. The greatest density on any British Railway route in 1965 was 5 million passengers a year, so that there seem at present to be no routes in Britain on which the hovercraft would be cheaper than the trains. The ideal hovercraft route must be one on which the density of traffic makes the idea economically attractive but long enough to make use of the greater speed the hovercraft offers. Nothing in Britain can compete effectively with the Northeast Corridor in the United States as a route for introducing hovercraft. The hovercraft men in Britain may have to turn their sights to Stansted if the Government really decides to make that London's third airport, but that is another matter-political as well as eeonomic.

All this is not to say that hovercraft will never supply an acceptable alternative to conventional systems of transport, but they are obviously more attractive where alternative systems are slow and inconvenient, as with the cross-Channel ferries. Even there, the Channel Tunnel may reduce the amount of traffic carried above the surface. Where existing systems operate at higher speeds and are capable of considerable development, the case for hovercraft looks slim. British Rail, losing $£ 130$ million a year on rail services, has been castigated for its reluctance to embrace the hovercraft. In retrospect, it may turn out to have been wiser to concentrate on the improvement of existing services.

\section{ASK FOR MR JONES}

ThE British Government is well on the way to making a great muddle of its policies towards the nationalized industries, particularly in fuel and power. The immediate cause of trouble is the announcement two weeks ago of higher prices for the electricity sold to domestic consumers. It has been known since May this year that electricity prices would have to go up, but domestic consumers (who are also usually voters) have not taken kindly to the suggestion that they will have to pay an extra 16 per cent. Mr Richard Marsh, the Minister of Power and the custodian of electricity 
prices, only has himself to blame that his holiday in Jugoslavia was cut short by the excitement, and that the Prime Minister has agreed that all future charges levied for products or services by the nationalized industries shall first of all be examined by the Prices and Ineomes Board. It does not take a particularly long memory to appreciate that this will bring pleasure to Mr Aubrey Joncs, the chairman of the Prices and Ineomes Board, for his complaint that the Government should have given him a chance to examine this latest increase of price seems to have been fully vindicated. If things go on like this, people will be wondering who is the Prime Minister-Mr Wilson or Mr Jones.

Although the problem of what prices the nationalized industries should charge may on the face of it scem to be an exceedingly academic issue, the fact that these industries between them are responsible for more than a sixth of the industrial activity in Britain is a sufficient proof that the London School of Economics cannot be left entirely in charge. By what may seem to some to be a pleasing poetic justice, the rules by which the nationalized industries are at present regulated have their roots in the late fifties, when the electricity industry invited the enmity of the Treasury by the size of its capital investment each year in new power stations and transmission plant. In the competition for capital, private industry was starved of funds, and it became apparent that nothing in the original acts of nationalization laid down how much the nationalized industries should seek to earn by way of surplus on their trading. From there it was a short step to the White Paper of April 1961 by means of which each nationalized industry was told to earn a surplus each year defined as a certain percentage of the net capital assets employed. Electricity was asked to shoulder the heaviest burden, presumably but illogically because it was the only one of the nationalized industrios to have consistently made a profit in the fifties. Ironically, the chief reason why electricity prices must now be increased is that the industry is hard pressed to raise the whole of the 12.4 per cent of the surplus which is specified.

So should the charges be abolished? This is what a great many people will say when bigger bills come in for payment in the months ahead. The simple answer is that they are indispensable. Just as other kinds of industries must make provision out of their earnings for the depreciation of plant and for the raising of capital, so nationalized industries must keep their books in proper order. In 1965-66, for example, the elcctricity industry put aside $£ 330$ million to cover these charges, and also earned a surplus of $£ 85$ million. Taken altogether, these sums of money were 12.6 per cent of the net capital employed, or more than enough to satisfy the industry's statutory obligation. Yet in the same year investment cost $\$ 595$ million, so that the electricity industry consumed more public money than it paid to the Exchequer. Obviously the only sensible question to ask about the charges is whether they should be varied by some small amount, one way or the other.
To begin with, there is a strong case for asking that nationalized industries in competition with each other -coal, gas and electricity, for example, or the two nationalized airlines-should have similar charges laid against them. One of the anomalies of the past few years has been that electricity has been more highly taxed than gas-a sign of how the gas industry seemed to be languishing when the charges were first specified in the early sixties. There is now the most urgent case for equalizing these two and also for making the coal industry pay a fair return on the capital it employs.

The charges should also be administered more flexibly. The sharp increase of electricity prices last week has come about because the industry has had to meet a number of unexpected costs in the course of a single year's operation. The demand has fallen behind the forward estimates on which the industry has based its calculations, principally because the Government's own economic plan has fallen into disarray. Some power station equipment has been slow in coming into service, which has also increased the industry's costs without adding to its productive capacity. In circumstances like these, it is essential that the nationalized industries should be able to spread hardship over more than the year in which it occurs. It would even make sense if the financial objectives set for the industries could be defined not by a single number but by some variable relationship with the parameters which affect the industry's operations. It would make sense, for example, to have a lower financial objective when the economy as a whole is lagging.

It is not at this stage clear whether the Prices and Incomes Board will have a chance to examine issues like these. According to the Prime Minister, the financial objectives are to remain the Government's prerogative, and a new version of the White Paper of 1961 is due to appear soon. But Mr Jones is a resourceful man, and it will be surprising if he does not find some way of pointing out that the present system is so cut and dried that it is an impediment to efficiency, not a help. But, even if the Prices and Incomes Board has for a time to cxamine the side issues, there are plenty of important questions to be asked. It would, for example, be good to know whether the electricity industry is cntirely justified in its devotion to such a closely integrated transmission network that all the generating stations in the country can operate effectively as a single unit. A more general version of the same question is whether the public interest would be served if the industry deliberately offered a poorer service for a lower price. Certainly it is pertinent to ask why the industry should have accumulated an extra 17 per cent of generating capacity to guard against the chance that the coming winter will be exceptionally severe. In other words, by asking the right questions the Prices and Incomes Board can do a great deal not merely to rationalize the way in which the nationalized industries make use of scarce resources but also to ensure that they conduct themselves efficiently. 